Portland State University

PDXScholar

$10-2020$

\title{
Data Files: The Role of Bus Stop Features in Facilitating Accessibility
}

\author{
Keith Batholomew \\ University of Utah \\ Ja Young Kim \\ University of Utah \\ Divya Chandrasekhar \\ University of Utah \\ Reid Ewing \\ University of Utah \\ Arlie Adkins \\ University of Arizona
}

See next page for additional authors

Follow this and additional works at: https://pdxscholar.library.pdx.edu/trec_data

Part of the Transportation Commons, Urban Studies Commons, and the Urban Studies and Planning

Commons

Let us know how access to this document benefits you.

\section{Recommended Citation}

Bartholomew, K., Kim, J., Chandrasekhar, D., Ewing, R., Adkins, A. \& Jensen, S. Data From: The Role of Bus Stop Features In Facilitating Accessibility. NITC-RR-1214. Portland, OR: Transportation Research and Education Center (TREC), 2020. https://doi.org/10.15760/TREC_datasets.09

This Dataset is brought to you for free and open access. It has been accepted for inclusion in TREC Datasets and Databases by an authorized administrator of PDXScholar. Please contact us if we can make this document more accessible: pdxscholar@pdx.edu. 


\section{Authors}

Keith Batholomew, Ja Young Kim, Divya Chandrasekhar, Reid Ewing, Arlie Adkins, and Samuel Jensen 
Title

Data Files: The Role of Bus Stop Features in Facilitating Accessibility

Authors:

Keith Bartholomew (University of Utah)

Ja Young Kim (University of Utah)

Divya Chandrasehkar (University of Utah)

Reid Ewing (University of Utah)

Arlie Adkins (University of Arizona)

Samuel Jensen (University of Arizona)

Sponsor

This project was supported by the National Institute for Transportation and Communities (NITC; grant number 1214), a U.S. DOT University Transportation Center, and the Utah Department of Transportation (Grant number 19-8318).

Document Type

Datasets - Excel files

Abstract

These datasets support a final report published on NITC's website "The Role of Bus Stop Features in Facilitating Accessibility": https://nitc.trec.pdx.edu/research/project/1214.

The DOI for the final report is: https://archives.pdx.edu/ds/psu/34322

\section{Description}

UTA Paratransit Activity Locations 2018

Utah Transit Authority data were retrieved from the Trapeze database by Jim Wadley, jwadley@rideuta.com, on 31 January 2019. The LDate field is a long integer of the date in YYYYMMDD format. An Activity of 0 is a pick-up and 1 is a drop-off. There are some activities not geocoded that have a Lat and Lon of 0 .

UTA Stop Ridership 2013 and 2018 change days

Data are from APC data collected on 5 - 7 February 2019 by Jim Wadley (jwadley@rideuta.com)

They were retrieved using the Stop Ridership Ranking report and SPSS. Data periods are entire "change day" periods. Dates covered are in the tab names. Approximately $50 \%$ of buses were equipped with APC equipment in 2013. Ridership was not sampled in 2013 so stops may have had few or no APC records. By 2014 approximately $80 \%$ of buses were APC equipped and sampling plans were being implemented with the goal of using APC equipment for ridership reporting. It is still possible, however, that not all stops were adequately sampled. By 2018 100\% of the bus fleet were using APC's. All trips are sampled, with data missing only in the case of detour or equipment failure. Average daily stop activity is derived by summing the averages of all the daily trips sampled at a stop. Overall ridership is calculated from the average daily ridership on complete trips, therefore the sum of stop ridership on a route may not equal route ridership. Stopld is the internal ID for the Trapeze scheduling and bus stop management software used by UTA. UTAId is the six-digit ID for customer stop identification. Bus stop signs are marked with this ID. AverageDailyOn are the average boardings for the service (Weekday, Saturday, or Sunday) during the change day period. AverageDailyOff are the alightings. TotActivty is the sum of the two. Latitude and Longitude are the are the averages of the bus GPS locations at the time of boarding and alighting. 